\title{
PENGATURAN DAN PERLINDUNGAN HUKUM TENAGA KERJA MIGRAN LINTAS NEGARA DALAM PERSPEKTIF HUKUM INTERNASIONAL
}

\author{
Josep Robert Khuana, Program Magister (S2) Ilmu Hukum \\ Fakultas Hukum Universitas Udayana, E-mail : robertkhuana2020@gmail.com
}

doi: $\underline{\text { https:// doi.org/10.24843/KS.2020.v08.i08.p14 }}$

\begin{abstract}
Abstrak
Tujuan dari penelitian ini untuk mengetahui dan menganalisis perlindungan hukum bagi tenaga kerja WNI yang bekerja di luar negeri perspektif hukum nasional dan hukum internasional. Metode penelitian yang digunakan adalah metode penelitian hukum normatif, dengan menggunakan pendekatan perundang-undangan dan pendekatan kasus, norma-norma hukum/kaidah-kaidah yang berkaitan dengan permasalahan hukum yang dibahas, dilengkapi dengan kasus-kasus yang terjadi saat ini. Adapun hasil yang diperoleh dari penelitian ini adalah perdagangan manusia merupakan isu Hak Asasi Manusia dalam masyarakat intemasional yang berkembang dengan fokus permasalahan prostitusi yang melibatkan perempuan dan anak-anak, seiring dengan berjalannya waktu, perkembangan jaman serta meningkatnya permintaan, perdagangan manusia tidak lagi berpusat dalam bidang prostitusi, tetapi juga digunakan dalam bentuk praktek-praktek kerja paksa, perbudakan serta penjualan/pemindahan organ-organ tubuh. Dalam upaya mengatur perlindungan buruh migran, majelis umum PBB melalui Resolusi No. 45/158 di New York pada 18 Desember 1990 membuat payung hukum dengan mengeluarkan International Convention on the Protection of the Rights of All Migrant Workers and Members of Their Families. Dalam upaya pelaksanaan perlindungan hukum terhadap tenaga kerja migran, PBB melalui International Labour Organization (ILO) mengeluarkan konvensi-konvensi yang berkaitan dengan perlindungan buruh migran. Upaya menanggulangi maraknya kasus perdagangan manusia yang tak lepas kaitannya dalam upaya perlindungan buruh migran Indonesia berkomitmen untuk melaksanakan Protocol to Prevent, Suppress and Punish Trafficking in Persons, Especially Women and Children dan menerbitkan Undang-Undang Nomor 21 Tahun 2007 tentang Pemberantasan Tindak Pidana Perdagangan Orang (UU PTPPO).
\end{abstract}

Kata Kunci : Perlindungan Hukum; Pekerja Migran; Hukum Internasional

\begin{abstract}
The purpose of this study is to find out and analyze the legal protection of Indonesian citizens working abroad from the perspective of national and international law. The research method used is a normative legal research method, using legal approaches and case approaches based on laws and regulations, norms of law / rules relating to legal issues discussed, are equipped with cases which is happening now. The results obtained from this research, human trafficking is a Human Rights issue in the evolving international community with the focus of prostitution issues involving women and children, as time goes on, the times of development and increased demand, human trafficking is no longer centered in the field prostitution, but also used in the form of forced labor, slavery and sale /removal of organs. In an effort to protect the protection of foreign workers, the UN General Assembly through Resolution No. 45/158 in New York on 18 December 1990 made a legal umbrella by issuing the International Convention on the Protection of the Rights of All Migrant Workers and Members of Their Families. In an effort to implement legal protection against foreign workforce, the United Nations through the International Labor Organization (ILO) issues conventions related to the protection of foreign workers. The efforts address the widespread human trafficking case in Indonesian migrant workers' protection is committed to implementing Protocol to Prevent, Suppress and Punish Trafficking in Persons, Especially Women and Children and to issue Law Number 21 Year 2007 on the Eradication of Trafficking in Persons.
\end{abstract}


Keywords : Legal Protection; Migrant Workers; International Law

\section{Pendahuluan}

\subsection{Latar Belakang Masalah}

Setiap negara berdaulat sudah pasti sebagai ciri sebuah negara akan memiliki penduduk atau warga negaranya, mempunyai yuridiksi atau matra laut darat dan udara serta struktur pemerintahan yang diatur oleh hukum nasionalnya masing masing. Tiap negara bernaung dibawah konstitusi sebagai landasan yuridis - filosofis - sosiologis dalam penyelenggaraan kehidupan kesejahteraan warga negaranya. Warga negara suatu negara bukan saja wajib tunduk pada hukum positif atau hukum nasionalnya sendiri, juga wajib tunduk secara sukarela walaupun tidak mengikat mutlak dari primat hukum internasional. Berbagai konvensi di bidangnya masingmasing negara-negara dibawah naungan organisasi internasional PBB telah sepakat mengikatkan diri untuk mentaati aturan universal seperti konvensi yang melindungi buruh atau tenaga kerja migran yang berkiprah lintas yuridiksi antar negara. Kalau konvensi atau hukum nasional negara pihak dilanggar akan menimbulkan kriminalisasi yang tergolong kejahatan transnasional (transnational crimes) .

Kejahatan transnasional menyangkut tenaga kerja atau buruh lazimnya dilakukan oleh pelaku sindikat penyelundup lintas batas yuridiksi dari negara yang satu ke negara lain / asing dilakukan oleh kelompok yang terorganisasi secara rapi, serius dan terselubung. Jaringan mereka ini dalam kiprahnya melibatkan beberapa negara, seperti negara pengirim / penyelundup, negara tempat transit dan negara tujuan akhir. Terkait cara-cara serta modus para pelaku kejahatan terorganisasi dengan para korbannya tenaga kerja migran lintas yuridiksi negara, dipahami sebagai kejahatan serius yang dilakukan oleh kelompok pelaku tindak pidana terorganisasi. ${ }^{1}$

Elemen kejahatan transnasional terorganisir dengan unsur - unsur terjabar diatas, senada dengan pandangan ahli Jay S. Albanese yang mendefinisikan kejahatan transnasional terorganisasi adalah sebuah upaya yang terus ada dan beroperasi secara rasional untuk mengeruk kepentingan dari aktivtias ilegal yang sering kali sangat dibutuhkan masyarakat. Eksistensinya terus dijaga dengan menggunakan kekerasan, ancaman, kontrol monopoli dan / atau menyuap para pejabat pemerintah. ${ }^{2}$

Setiap negara yang memiliki kedaulatan akan menjalin hubungan dengan pihak luar. Satu negara tidak bisa menutup diri dalam menyelenggarakan pemerintahannya. Apapun bentuk dan tipe pemerintahan yang dianutnya tujuannya sama guna kemakmuran rakyat atau bangsanya.

Kurangnya lapangan kerja di dalam negeri mengakibatkan banyak warga negara yang mencoba mengadu nasib mencari pekerjaan ke luar negeri, dengan harapan akan dapat memenuhi kebutuhan-kebutuhan pokok bagi diri dan keluarga mereka (sandang, pangan dan papan). Kepergian warga negara Indonesia ke luar negeri dengan tujuan mencari pekerjaan dibenarkan oleh UUD Negara Republik Indonesia Tahun 1945 Pasal 27 ayat (2) dan perubahannya yang tersurat "tiap-tiap warga negara berhak atas pekerjaan dan penghidupan yang layak bagi kemanusiaan".

1 Obokata, T., “The Value of International Law in Combating Transnational Organized Crime in the Asia - Pacific", Asian Journal of International Law, Volume 7, 2015, h.. 41

2 Albanese, J.S., Kejahatan Terorganisasi (Organized Crime Akar dan Perkembangannya, Edisi Keenam, Prenada Media Group, Jakarta, 2016, h. 5. 
UU No. 39 Tahun 1999 Pasal 38 ayat (2) tentang Hak Asasi Manusia menyatakan bahwa - warga negara berhak dengan bebas memilih pekerjaan yang disukainya. Oleh karenanya, warga negara Indonesia tidak dapat dilarang untuk bekerja dimana saja, termasuk diluar negeri. Sri Soemantri Martosoewignjo menyatakan HAM adalah hakhak dasar yang melekat pada diri manusia secara kodrati dan universal sebagai karunia Tuhan Yang Maha Esa, dan berfungsi menjaga integritas keberadaannya yang tidak boleh diabaikan, dikurangi atau dirampas oleh siapa pun, meliputi hak untuk hidup, hak untuk melangsungkan keturunan, hak pengembangan diri, hak keadilan hak kemerdekaan, hak keamanan dan hak kesejahteraan. ${ }^{3}$ John Materson dari Komisi HAM PBB menyatakan HAM adalah sebagai hak-hak yang melekat pada manusia, yang tanpa hak-haknya manusia mustahil dapat hidup sebagai manusia. ${ }^{4}$

Saat perdagangan orang bisa dianggap sebagai perbudakan modern, saat itu juga perdagangan orang merupakan salah satu persoalan penting yang harus dicari jalan keluarnya untuk menekan tingkat pertumbuhan kekerasan/kejahatan ini di dunia. Adapun beberapa golongan pekerjaan yang dijadikan obyek perdagangan orang, yaitu sebagai berikut:
a. Pembantu Rumah Tangga
b. Pelayan Restoran
c. Buruh Pabrik dan Perkebunan
d. Industri Hiburan / Pekerja Sex Komersial, dan lain-lain

Perdagangan orang dapat terjadi antar pulau atau daerah dalam satu wilayah negara. Namun belakangan ini perdagangan orang lazim terjadi lintas batas negara, sehingga tergolong dalam kategori kejahatan transnasional atau transnational crime. Menurut konsep pengertian diberikan oleh Passas N. bahwa transnational crime adalah "Prilaku yang membahayakan kepentingan yang dilindungi oleh hukum di lebih dari satu yurisdiksi nasional dan yang dikriminalisasi dalam setidaknya oleh salah satu negara atau yurisdiksi yang terkait. ${ }^{5}$

Karya tulis ini merupakan karya tulis ilmiah masih orisinal atau tidak sama dengan karya tulis ilmiah lain sebelumnya. Ada beberapa karya tulis ilmiah lain seperti : 1. Dari Penulis nama : Yusri Susanti, Program Pascasarjana Fakultas Hukum UGM - Yogyakarta (2017), dengan judul Analisis Penegakan Hukum terhadap penyelundupan migran dengan rumusan masalah (1) Bagaimana pengaturan dalam hukum positif Indonesia menyangkut penyelundupan imigran? (1) Bagaimana semestinya pengaturan penyelundupan imigran bagi indonesia agar tidak melanggar hak-hak asasi imigran?2. Penulis Abdullah Rifski, dari bagian hukum internasional Fakultas Hukum Universitas Hasanuddin-Makasar (Tahun 2015) dengan judul "Penyelundupan Migran Oleh Penyelundup Warga Negara Indonesia (WNI) ditinjau dari Conversi Palermo 2000" dengan rumus masalah (1) Bagaimana Conversi Palermo mengatur tentang penyelundupan ilegal oleh WNI atas imigran tersebut? (2) Bagaimana tanggung jawab hukum oleh pemerintah Republik Indonesia terhadap

\footnotetext{
${ }^{3}$ Martosoewignjo, S.S "Refleksi HAM di Indonesia”, Makalah Penataran Hukum Humaniter dan Hukum HAM. UGM-ICRC. Yogyakarta, 1998, h. 12.

4Santoso, B., "Wawasan HAM dalam Negara Hukum", Makalah Seminar HAM, FHUNS, Surakarta, 2001, h. 3.

5 Passas N., "Cross - Border Crime and The Interfase Between Legal and Ilegal Actors", Security Journal, Volume 16, 2003, h. 13
} 
imigran Warga Negara Indonesia yang ditelantarkan di negara tujuan?3. Penulis Momon Sitompul dari Fakultas Hukum Universitas Sebelas Maret Surakarta (2016), dengan judul hukum :"Penyelundupan Migran di Perairan Indonesia Ditinjau Dari Hukum Internasional" dengan rumusan masalah.(1)Bagaimana pengaturan oleh Convensi hukum laut menyangkut penyelundupan migran lintas negara? (2) Bagaimana tanggung jawab pemerintah Indonesia dalam penanganan penyelundupan migran di wilayah perairan Indonesia.

\subsection{Rumusan Masalah}

Berdasarkan uraian latar belakang diatas rumusan masalahnya adalah (1) Bagaimana pengaturan menurut hukum nasional dan hukum internasional bagi tenaga kerja migran lintas negara ? (2) Bagaimana perlindungan hukum bagi tenaga kerja migran lintas negara perspektif hukum internasional ?

\subsection{Tujuan Penelitian}

Tujuan dari penelitian ini untuk mengetahui dan menganalisis perlindungan hukum bagi tenaga kerja WNI yang bekerja di luar negeri ditinjau dari perspektif hukum nasional dan hukum internasional.

\section{Metode Penelitian}

Penelitian ini menggunakan jenis penelitian hukum normatif. Menurut Bahder Johan Nasution mengemukakan bahwa "Penelitian hukum normatif adalah metode yang meneliti aturan - aturan hukum positif sebagai norma tertulis yang dibuat secara resmi dan diundangkan oleh pemerintah. ${ }^{6}$ Pendekatan yang digunakan berupa pendekatan perundang-undangan dan pendekatan kasus. Sumber bahan hukumnya bahan hukum primer berupa dasar perundang-undangan (hukum - positif nasional) dan aturan hukum universal seperti konvensi - konvensi terkait materi. Ditunjang oleh bahan hukum subsidair dari buku-buku hukum (internasional), jurnal ilmiah, hasil penelitian, berita - internet, serta bahan tersier berupa kamus hukum dan ensklopedia.

\section{Hasil dan Pembahasan}

\subsection{Pengaturan dan Tanggung Jawab Negara Terhadap Tenaga Kerja Migran}

\subsubsection{Konvensi Buruh Migran dan Protokol Palermo}

Buruh migran, mengacu kepada Konvensi ILO pada Buruh Migran tahun 1949, (No.97) pada article 11, adalah orang yang bermigrasi dari suatu negara ke negara lain untuk tujuan bekerja. Menurut Departemen Sosial, definisi buruh migran (Indonesia) adalah orang yang berpindah ke daerah lain, baik di dalam maupun ke luar negeri (legal maupun ilegal), untuk bekerja dalam jangka waktu tertentu. Berdasarkan UU No. 39 Tahun 2004 tentang Penempatan dan Perlindungan Tenaga Kerja Indonesia di Luar Negeri Pasal 1 ayat 1, definisi Tenaga Kerja Indonesia yang selanjutnya disebut

${ }^{6}$ Nasution, B.J., , Metode Penelitian Ilmu Hukum, Penerbit Mandar Maju, Bandung, 2008, h. 
TKI adalah setiap warga negara Indonesia yang memenuhi syarat untuk bekerja di luar negeri dalam hubungan kerja untuk jangka waktu tertentu dengan menerima upah7.

Jika diurutkan dengan negara-negara di benua Asia, Indonesia berada di peringkat 3, dibawah Srilangka dan Filipina, dalam hal jumlah pengirim buruh migran. Menurut BNP2TKI, sebesar 6 juta orang buruh migran internasional berasal dari Indonesia (2009). Dari sudut pandang kuantitas, jumlah buruh migran (menurut Depnakertrans) pada tahun 2007 mencapai 696.746 orang dan tahun 2008 meningkat menjadi 900.129 orang. Dari jumlah itu 90\% diantaranya perempuan yang bekerja sebagai pekerja rumah tangga. Dari jumlah itu negara-negara yang menjadi tujuan pengiriman buruh migran diantaranya 257.217 ke Arab Saudi, 222.198 ke Malaysia, 37.496 ke Singapura, dan 28.184 ke Uni Emirat Arab. ${ }^{8}$

Payung hukum tenaga kerja migran yang bekerja lintas negara dimanapun menjadi negara tujuan migran untuk bekerja tetap tunduk pada konvensi internasional yang dikeluarkan oleh PBB, melalui bagian organisasi buruh dunia yakni ILO. Tiap negara pengirim migran mesti menghormati dan memiliki hak menerapkan prinsip kedaulatan teritorial internal ekslusif maupun eksternal yang setara. ${ }^{9}$

Pada tingkat internasional, payung hukum yang mengatur perlindungan buruh migran ada pada Konvensi Internasional Mengenai Perlindungan Hak Semua Pekerja Migran dan Anggota Keluarganya. Konvensi tersebut dideklarasikan di New York pada 18 Desember 1990 dan diberlakukan sebagai hukum pada 1 juli 2003. Sebagai anggota PBB, Indonesia ikut menandatangani konvensi ini pada 22 September 2004. Buruh migran memiliki posisi yang penting karena buruh migran telah memberikan sumbangan pada kepentingan nasional berupa sumbangan devisa atau biasa disebut dengan remittances. Buruh migran memberikan remittances yang tidak sedikit, yaitu antara 1 sampai 6 kali per tahun dengan total jumlah per transaksi sekitar 200-500 US\$.

Menurut Surtees, permasalahan yang berkaitan dengan buruh migran diantaranya: kekerasan, penyalahgunaan (penyimpangan), pemalsuan dokumen, pemberian informasi yang salah. Bicara mengenai buruh migran Indonesia, permasalahan yang kerap mencuat adalah:

1. Minimnya perlindungan.

2. Adanya kekerasan dan penyiksaan terhadap buruh migran.

3. Ancaman hukuman penjara sampai hukuman mati.

4. Relatif tingginya jumlah buruh migran yang tewas.

5. Sistem penempatan dan perlindungan negara pengirim pekerja migran belum mengacu kepada kesepakatan internasional.

6. Di luar negeri, majikan memiliki kekuasaan yang absolut. Majikan umumnya menyimpan dokumen untuk menekan buruh migran. Ketika buruh migran lari dari majikan, maka berstatus ilegal dan dianggap melanggar hukum,

7Pusat Kajian FISIP UI, Persoalan Buruh Migran di Indonesia: IdentifikasiMasalah-masalah Buruh Migran, 2014, URL: http://www.puskapol.ui.ac.id/wp-content/uploads/2014/05 ffact-sheet-2.pdf, diakses pada: 15 Maret 2017

$8 \mathrm{Ibid}$

${ }^{9}$ Florea, D., "Sovereign State The Classic Basic Subject of Public International Law", , The USV, Analis of Economic and Public Administration University of Succava Romania, Volume 12, 2012, h. 1 
7. Jumlah buruh migran yang banyak membuat negara-negara penerima punya banyak pilihan untuk lebih mempekerjakan buruh migran murah yang tidak terlalu banyak menuntut hak-haknya.

8. Indonesia kesulitan mempengaruhi negara lain untuk melindungi buruh migran.

9. Pemerintah kurang memperhatikan pelanggaran HAM yang menimpa buruh migran Indonesia.

10. Kebijakan yang ada menempatkan buruh migran sebagai komoditi yang diperdagangkan yang menjadi titik awal banyaknya pelanggaran HAM yang menimpa buruh migran. ${ }^{10}$

Konvensi Pekerja Migran tahun 1990 merupakan kerangka paling luas dalam hukum internasional dan mencakup perlindungan terhadap orang-orang yang berencana menjadi pekerja migran, sedang bekerja di luar negara, atau selesai bekerja di luar negara dan kembali ke negara asal. Konvensi Pekerja Migran tahun 1990 memberikan definisi mengenai istilah pekerja migran yang disepakati secara internasional dan dibedakan menjadi pekerja frontier, pekerja musiman, pelaut, pekerja pada instalasi lepas pantai, pekerja keliling, pekerja proyek, pekerja dengan pekerjaan tertentu dan pekerjaan mandiri yang bisa diterapkan di setiap kawasan di dunia.

Konvensi Pekerja Migran tahun 1990 memiliki tujuan untuk melindungi kepentingan para pekerja saat dipekerjakan di Negara-negara yang bukan negaranya sendiri. Perlindungan yang diatur dalam konvensi ini menekankan pada peranan dokumen para pekerja migran yang sah. Dokumen pekerja migran yang sah akan menjamin tidak adanya pelanggaran dalam proses migrasi tenaga kerja, misalnya pelanggaran atas batas umur pekerja migran. Dokumen tersebut juga akan membantu untuk meminimalisir terjadinya praktek perdagangan dan penyeludupan manusia.

Pekerja migran rawan menjadi korban praktek perdagangan manusia, maka negara melalui hak yurisdiksi teritorialnya yang ekstra tersebut memiliki kewenangan atas masalah terkait. Perkembangan yang terjadi pada akhir tahun 90-an, Frederick Mann mengamati bahwa :

"Biasanya tidak ada negara yang diizinkan untuk menerapkan undang-undang kepada orang asing sehubungan dengan tindakan yang dilakukan oleh mereka di luar dominasi kekuasaan kedaulatan yang berlaku. Itu adalah aturan berdasarkan hukum internasional, dimana kekuatan kedaulatan terikat untuk menghormati subyek dan hak-hak seluruh kekuatan kedaulatan di luar wilayahnya sendiri". ${ }^{11}$

Selama abad ke-19 beberapa yurisdiksi Eropa mulai mengklaim yurisdiksi atastindakan ekstrateritorial yang dilakukan oleh bukan warga negara yang mengancam keamanan negara. ${ }^{2}$ Dibawah hukum kebiasaan internasional ada lima prinsip yang diakui secara umum dimana suatu negara dapat secara sah menyatakan

${ }^{10}$ Ibid

${ }^{11}$ Sitepu, A.I, "Application Of Extraterritorial Jurisdiction In European Convention On Human Rights (Case Study: Al-Skeini And Others V. UK)", Jurnal Hukum-Internasional, Volume 13, 2016, h. 357

${ }^{12}$ Ireland, Danielle, "Prosecution of Extraterritorial Criminal Conduct and the Abuse of Rights, DoctrineUtrecht Law Review", Volume 9, 2013, h 69 
yurisdiksi extrateritorial. ${ }^{13}$ Begitu pula dinyatakan sebagai dasar yurisdiksi ekstrateritorial meliputi prinsip - prinsip seperti : 1. Adanya prinsip teritorial, 2. Adanya prinsip kewarganegaraan, 3 . Adanya prinsip universalitas, 4 . Adanya prinsnip perlindungan, dan 5 . Adanya prinsip efek. ${ }^{14}$

Dan pada tanggal 12 April 2012 Indonesia telah meratifikasi Konvensi PBB Tahun 1990 tentang Perlindungan Hak-Hak Seluruh Pekerja Migran dan Anggota Keluarganya, (selanjutnya disebut Konvensi Pekerja Migran). Konvensi ini pertama kali dideklarasikan di New York pada tanggal 18 Desember 1990 dan diberlakukan sebagai hukum internasional pada tanggal 1 Mei 2003. Indonesia telah menandatangani Konvensi ini pada tanggal 22 September 2004. Sejauh ini negara yang telah meratifikasi Konvensi ini hanya berjumlah 35 negara dan di wilayah ASEAN hanya baru Philipina dan Indonesia. ${ }^{15}$

Indonesia sebagai salah satu negara pengirim tenaga kerja terbesar ke luar negeri sudah selayaknya meratifikasi Konvensi ini, meskipun negara-negara tujuan penempatan kerja migran Indonesia belum ada yang meratifikasi, seperti Malaysia dan Arab Saudi. Ratifikasi Konvensi ini sangat penting karena dapat menunjukkan pada dunia internasional tentang komitmen suatu negara dalam melakukan perlindungan bagi pekerjanya yang bekerja diluar negeri. Di sisi lain, dengan meratifikasi Konvensi berarti Pemerintah berkewajiban unruk memberikan peluang dan kesempatan yang sama bagi tenaga kerja asing/pekerja migran dan anggota keluarganya yang bekerja di Indonesia termasuk apabila mereka terkena PHK dan berkewajiban untuk memberikan tunjangan pengangguran.

Konvensi diatas mengatur beberapa hal penting, seperti :

1. Mengatur mengenai standar minimum perlindungan hak-hak sipil, politik, ekonomi, sosial dan budaya seluruh pekerja migran dan anggota keluarganya. Konvensi ini mendorong negara agar menyelaraskan perundang-undangannya dengan standar universal yang termaktub dalam Konvensi.

2. Mengakui adanya kontribusi yang disumbangkan oleh pekerja migran terhadap ekonomi dan masyarakat negara tempat mereka bekerja serta pembangunan negara asal mereka.

3. Mencantumkan serangkaian standar untuk perlindungan pekerja migran dan kewajiban negara yang terkait, meliputi negara asal, transit dan negara tempat bekerja.

4. Mencegah dan menghapuskan eksploitasi seluruh pekerja migran dan anggota keluarganya di seluruh proses migrasi, termasuk mencegah terjadinya perdagangan manusia.

${ }^{13}$ Boister, N.," Transnational Criminal Law", EJIL, Volume 14, 2003, h. 12

${ }^{14}$ De Pue, D., "Fundamental Principles Governing Extraterritorial Prosecutions Jurisdiction and Venue", United States Attorneys Bulletin, Washington DC, Volume 55, 2007, h. 3

15 Serena, E., Konvensi РВB Tahun 1990: Suatu Keniscayaan Dalam Perwujudan Emansipasi 7X7, 2014, URL : http://www.kompasiana.com/elsonserenasiagian/konvensi-pbb-tahun1990-suatu-keniscayaan-dalam-perwujudan-emansipasi-tki_54f75b60a3331145398b45dc, diakses pada : 15 Maret 2017 
5. Konvensi ini tidak hanya melindungi para pekerja migran, tapi juga melindungi kepentingan negara penerima pekerja migran terkait dengan pembatasan akses kategori pekerjaan guna melindungi warga negaranya. ${ }^{16}$

Konvensi yang disahkan oleh Majelis Umum PBB pada 18 Desember 1990 melalui Resolusi No. 45/158 ini awalnya merupakan inisiatif negara-negara asal pekerja migran untuk membentuk suatu standar perlindungan dengan lebih spesifik. Konvensi merupakan hasil dari kajian, dialog dan perdebatan mendalam antara dua sisi pemikiran, baik yang mewakili kepentingan negara asal pekerja migran, maupun negara tujuan.

Konvensi diatas mencakup pengaturan secara inti mengenai perlindungan migran secara internasional. Sehubungan dengan memahami esensi kejahatan transnasional tersebut bahwa hukum internasional terdiri dari unsur - unsur hukum domestik dan hukum internasional sehingga dinyatakan seperti : "dissolving traditional dichotomies between two"17

Konvensi tersebut juga memberikan peluang kepada Pemerintah guna mengontrol arus migran yang masuk ke Indonesia. Ketentuan ini dapat dilihat dalam Pasal 19 yang menegaskan bahwa:

"tidak satu pun ketentuan dalam Konvensi ini boleh mempengaruhi hak setiap negara pihak untuk menetapkan kriteria yang mengatur penerimaan pekerja migran dan anggota keluarganya."

Dengan kata lain, Konvensi sendiri telah memberikan jaminan bagi negara untuk menetapkan suatu kebijakan penerimaan pekerja migran dan anggota keluarganya yang dipandang sesuai dan sejalan dengan hukum nasional. Terlepas dari hal tersebut, Konvensi tetap memberikan perlindungan terhadap kepentingan negara penerimaan buruh migran untuk tetap memberikan jaminan lapangan pekerjaan terhadap warganya, dengan memberikan keleluasaan pembatasan akses kategori pekerjaan. Hal ini tertuang dalam Pasal 52 ayat 2 (a) Konvensi yang berbunyi:

"Terhadap tiap pekerja migran, negara tujuan kerja dapat membatasi akses pada kategori pekerjaan, fungsi, pelayanan atau kegiatan tertentu apabila diperlukan demi kepentingan negara tersebut dan ditetapkan oleh ketentuan hukum nasional. ${ }^{18}$

Ratifikasi ini tidak menimbulkan kerugian bagi Indonesia. Sebaliknya, ratifikasi ini dapat dijadikan modal untuk menggalang kekuatan internasional untuk menjalankan perlindungan pekerja migran Indonesia di luar negeri.

Negara-negara yang tergabung dalam protokol Palermo menyatakan bahwa tindakan-tindakan efektif untuk mencegah dan memerangi perdagangan manusia, terutama perempuan dan anak-anak, membutuhkan sebuah pendekatan internasional yang komperhensif di negara asal, negara transit, dan negara tujuan yang mencakup langkah-langkah untuk mencegah perdagangan, menghukum pelaku perdagangan, dan melindungi korban-korban perdagangan manusia, termasuk melindungi hak asasi mereka yang diakui secara internasional.

${ }^{16}$ Ibid

17 Qrentlicher, DF., “Whose Justice? Reconciling Universal Jurisdiction with Democratic Principle", Georgetown Law Journal, The Open University, Volume 92, 2004, h. 1067 ${ }^{18}$ Ibid 
Mengingat resolusi Majelis Umum 53/111 tanggal 9 Desember 1998, Majelis memutuskan untuk membentuk sebuah komite ad hoc antar pemerintah tanpa batasan dengan tujuan mengelaborasi sebuah konvensi internasional yang komperhensif untuk melawan kejahatan transnasional yang terorganisir dan untuk membahas elaborasi dari sebuah instrumen internasional yang menangani perdagangan terhadap perempuan dan anak-anak.

Maka negara-negara yang tergabung dalam protokol meyakini dengan menambah konvensi PBB terhadap kejahatan transnasional yang terorganisir dengan sebuah instrumen internasional untuk mencegah, membasmi dan menghukum perdagangan manusia khususnya wanita dan anak-anak, akan sangat bermanfaat untuk mencegah dan memerangi kejahatan tersebut. ${ }^{19}$ Berdasarkan protokol ini, definisi perdagangan manusia (human trafficking) adalah:

"...the recruitment, transportation, transfer, harboring, or receipt of persons, by means of the threat or use of force or other forms of coercion, of abduction, of fraud, of deception, of the abuse of power or of a position of vulnerability or of the giving or receiving of payments or benefits to achieve the consent of a person having control of another person, for the purposes of exploitation. Exploitation shall include, at a minimum, the exploitation of the prostitution of others or other forms of sexual exploitation, forced labour or services, slavery or practice similar to slavery, servitude or the removal organs." 20

Protokol Perdagangan Manusia Khususnya Perempuan dan Anak-anak diadopsi melalui Resolusi PBB A/RES/55/25. Protokol ini merupakan protokol tambahan dari Konvensi PBB tentang TOC yang harus selalu diinterpretasikan secara bersamaan dengan Konvensi TOC. Ketentuan-ketentuan yang terdapat di dalam Konvensi TOC berlaku secara mutatis mutandis terhadap protokol ini kecuali diatur lain di dalam protokol. Protokol Perdagangan Manusia Khususnya Perempuan dan Anak-anak mulai berlaku pada tanggal 25 Desember 2003 pada hari ke-90 setelah terdapat negara ke-40 yang meratifikasi atau mengakses. Sampai dengan Juni 2012 tercatat 117 negara yang telah menandatangani protokol dan 150 negara peserta.

Indonesia telah mengesahkan protokol ini pada tanggal 5 Maret 2009 dengan Undang-Undang Nomor 14 Tahun 2009 (UU 14/2009) tentang Pengesahan Protocol to Prevent, Suppres and Punish Trafficking in Persons, Especially Women and Children, Supplementing the United Nations Conventions Againts Transnational Organized Crime (Protokol untuk Mencegah, Menindak, dan Menghukum Perdagangan Orang, Terutama Perempuan dan Anak-Anak, Melengkapi Konvensi Perserikatan BangsaBangsa Menentang Tindak Pidana Transnasional yang Terorganisasi). ${ }^{21}$

\subsubsection{Peran Organisasi Internasional (I GO, IN GO) dan Negara Dalam Perlindungan Buruh Migran/Tenaga Kerja Lintas Negara}

Negara Republik Indonesia yang berdasarkan Pancasila dan Undang-Undang Dasar Negara Republik Indonesia Tahun 1945 menghormati dan menjunjung tinggi

${ }^{19}$ United Nations, Protocol to Prevent, Suppress and Punish Trafficking in Persons, Especially Women and Children. 2000,

${ }^{20} \mathrm{Ibid}$

${ }^{21}$ Santoso, M.I, Hukum Pidana Internasional, Pustaka Reka Cipta, Bandung, 2013, h. 151. 
harkat dan martabat manusia. Hak asasi manusia sebagai hak dasar yang secara kodrati melekat pada diri manusia, bersifat universal dan langgeng, juga dilindungi, dihormati, dan dipertahankan oleh Negara Republik Indonesia, sehingga perlindungan dan pemajuan hak asasi manusia, termasuk hak-hak seluruh pekerja mi gran dan anggota keluarganya perlu ditingkatkan.

Sebagai salah satu negara yang telah menandatangani International Convention on the Protection of the Rights of All Migrant Workers and Members of Their Families (Konvensi Internasional mengenai Perlindungan Hak-Hak Seluruh Pekerja Migran dan Anggota Keluarganya), Indonesia memiliki komitmen untuk meratifikasi Konvensi ini. Ratifikasi konvensi ini diharapkan dapat mendorong terciptanya ratifikasi universal dan penerapan prinsip serta norma standar internasional bagi perlindungan hak-hak seluruh pekerja mi gran dan anggota keluarganya secara global.

Dalam upaya melindungi, menghormati, memajukan dan memenuhi hak-hak pekerja migran dan anggota keluarganya, Pemerintah Indonesia telah membentuk berbagai peraturan perundang-undangan yang terkait dengan perlindungan terhadap tenaga kerja, antara lain:

1. Undang-Undang Nomor 4 Tahun 1979 tentang Kesejahteraan Anak;

2. Undang-Undang Nomor 39 Tahun 1999 tentang Hak Asasi Manusia;

3. Undang-Undang Nomor 23 Tahun 2002 tentang Perlindungan Anak;

4. Undang-Undang Nomor 13 Tahun 2003 tentang Ketenagakerjaan;

5. Undang-Undang Nomor 20 Tahun 2003 tentang Sistem Pendidikan Nasional;

6. Undang-Undang Nomor 39 Tahun 2004 tentang Penempatan dan Perlindungan Tenaga Kerja Indonesia di Luar Negeri;

7. Undang-Undang Nomor 40 Tahun 2004 tentang Sistem Jaminan Sosial Nasional;

8. Undang-Undang Nomor 12 Tahun 2006 tentang Kewarganegaraan Republik Indonesia;

9. Undang-Undang Nomor 21 Tahun 2007 tentang Pemberantasan Tindak Pidana Perdagangan Orang;

10. Undang-Undang Nomor 11 Tahun 2009 tentang Kesejahteraan Sosial;

11. Undang-Undang Nomor 36 Tahun 2009 tentang Kesehatan;

12. Undang - Undang Nomor 6 Tahun 2011 tentang Keimigrasian. ${ }^{22}$

Perlindungan tenaga kerja adalah upaya yang dilakukan untuk menciptakan kondisi agar setiap tenaga kerja dapat melaksanakan hak dan kewajibannya demi berlangsungnya sistem hubungan kerja yang harmonis yang dilakukan oleh seluruh lapisan masyarakat dalam berbagai kedudukan dan peranan yang menyadari betul pentingnya peranan tenaga kerja. Imam Soepomo, menyatakan bahwa:

"perlindungan hukum terhadap tenaga kerja adalah penjagaan agar tenaga kerja dapat melaksanakan pekerjaan yang layak bagi kemanusiaan". ${ }^{23}$

Menurut Soepomo perlindungan tenaga kerja dibagi menjadi 3 (tiga) macam, yaitu: perlindungan ekonomis, yaitu perlindungan tenaga kerja dalam bentuk penghasilan yang cukup, termasuk bila tenaga kerja tidak mampu bekerja diluar kehendaknya; perlindungan sosial, yaitu perlindungan tenaga kerja dalam bentuk

\footnotetext{
${ }^{22}$ Ibid

23 Soepomo, I., Hukum Perburuhan, Djambatan, Jakarta, 1987, h.78.
} 
jaminan kesehatan kerja, dan kebebasan berserikat dan perlindungan hak untuk berorganisasi; dan perlindungan teknis, yaitu perlindungan tenaga kerja dalam bentuk keamanan dan keselamatan kerja. ${ }^{24}$

Undang-undang Nomor 39 Tahun 2004 Tentang Penempatan dan Perlindungan Tenaga Kerja Indonesia dalam Pasal 1 menyatakan bahwa:

"Perlindungan TKI adalah segala upaya untuk melindungi kepentingan calon TKI/TKI dalam mewujudkan terjaminnya pemenuhan hak-haknya sesuai dengan peraturan perundang-undangan, baik sebelum, selama, maupun sesudah kerja."

Kaidah-kaidah mengenai tanggung jawab negara menurut prinsip-prinsip umum mengenai perlindungan warga negara di luar negeri bergantung pada terpeliharanya keseimbangan yang pantas antara dua hak fundamental negara: ${ }^{25}$ hak suatu negara untuk menjalankan yuridiksi di wilayah sendiri, bebas dari pengawasan negara-negara lain; dan hak suatu negara untuk melindungi warga negaranya di luar negeri.

Dalam upaya perlindungan terhadap buruh migran/tenaga kerja lintas negara terdapat aktor-aktor lain selain negara, peranan organisasi internasional dalam hubungan internasional saat ini telah diakui karena keberhasilannya dalam memecahkan berbagai permasalahan yang dihadapi suatu negara. Bahkan saat ini organisasi internasional dinilai dapat mempengaruhi tingkah laku negara secara tidak langsung. Kehadiran organisasi internasional mencerminkan keburuhan manusia untuk bekerjasama, sekaligus sebagai sarana untuk menangani masalah-masalah yang timbul melalui kerjasama tersebut. ${ }^{26}$ Menurut Teuku May Rudy definisi organisasi internasional adalah :

"Pola kerjasama yang melintasi batas-batas negara, dengan didasari struktur organisasi yang jelas dan lengkap serta diharapkan atau diproyeksikan untuk berlangsung serta melaksanakan fungsinya secara berkesinambungan dan melembaga guna mengusahakan tercapainya tujuan-tujuan yang diperlukan serta disepakati bersama, baik antara pemerintah dengan pemerintah maupun antara sesama kelompok non-pemerintah pada negara yang berbeda. ${ }^{27}$

Berdasarkan pengertian diatas, Teuku May Rudy secara tidak langsungmembagi organisasi internasional ke dalam dua pembagian besar, yakni organisasi internasional pemerintah (IGO) dan organisasi internasional non pemerintah (INGO). Adapun perbedaan antara INGO dan IGO adalah terletak dari anggotanya. Dimana anggota dari INGO adalah individu atau asosiasi tertentu yang kemudian bersama-sama membentuk organisasi atas dasar kepedulian akan nilai-nilai kemanusiaan. Sementara untuk IGO, merupakan organisasi yang anggotanya adalah Negara-negara ataupun pemerintah negara. Tidak berbeda dengan IGO, INGO yang

${ }^{24}$ Ibid

${ }^{25}$ Starke, J. G., , An Introduction To International Law (Pengantar Hukum International), Penyadur : F. Isjwara, Edisi Ke VI, Alumni Bandung, 1972h. 114.

26 Perwita, A.A.B dan Yani Y.M, , Pengantar Ilmu Hubungan Internasional, Remaja Rosdakarya, Bandung, 2005, h. 95.

27Rudy, T.M, Hukum Internasional, Refika Aditama, Bandung, 2002, h. 93. 
juga termasuk dalam klasifikasi organisasi internasional memiliki tujuan-tujuan tertentu yang harus dicapai. Seperti secara umum dijelaskan bahwa:

"Suatu organisasi internasional memiliki fungsi dalam menjalankan aktivitasnya, yang bertujuan mencapai tujuan yang diinginkan, yang berhubungan dengan pemberian bantuan dalam mengatasi masalah yang timbul terhadap pihak yang terkait. ${ }^{28}$

\subsection{Perlindungan Hukum Nasional dan Hukum Internasional Terhadap Tenaga Kerja Migran}

3.2.1. Perlindungan Hukum Nasional Tentang Perlindungan Tenaga Kerja Migran Berdasarkan Undang-Undang Nomor 21 Tahun 2007 tentang Pemberantasan Tindak Pidana Perdagangan Orang

Penyusunan UU PTPPO di Indonesia dimaksudkan untuk mewujudkan komitmen Indonesia untuk melaksanakan Protocol to Prevent, Suppres and Punish Trafficking in Persons, Especially Women and Children (Protokol Palermo tentang Mencegah, Memberantas dan Menghukum Tindak Pidana Perdagangan Orang, khususnya Perempuan dan Anak) dimana pada tahun 2002 keluar Keputusan Presiden RI No. 88 tentang Rencana Aksi Nasional Penghapusan Perdagangan Perempuan dan Anak, yang salah satu tujuan kuncinya adalah untuk mendorong dan atau menyempurnakan peraturan perundang-undangan yang berkaitan dengan perdagangan orang, khususnya perdagangan perempuan dan anak.

Dalam Pasal 1 Angka 2 UU PTPPO disebutkan bahwa tindak pidana perdagangan orang adalah setiap tindakan atau ' serangkaian tindakan yang memenuhi unsur-unsur tindak pidana yang ditentukan dalam UU No. 21 Tahun 2007.Sebelum Undang-Undang Permberantasan Tindak Pidana Perdagangan Orang (UU PTPPO) diterbitkan, larangan praktik perdagangan orang sudah diatur dalam produk hukum nasional, diantaranya:

Pada Pembukaan UUD 1945, alinea ke 4, Pancasila, Sila ke dua yaitu : "Kemanusiaan Yang Adil dan Beradab," menunjukkan bahwa perbudakan tidak dimungkinkan, apalagi berdasarkan Pasal 28 (1) negara menjamin "hak untuk tidak diperbudak" (amandemen ke-2,tanggal 18 Agustus 2000), dan dalam pasal - pasal Kitab Undang - Undang Hukum Pidana (KUHP) dan berbagai tindak pidana khusus.

\subsubsection{Perlindungan Hukum Terhadap Tenaga Kerja Migran Berdasarkan Hukum Internasional}

Organisasi Perburuhan Internasional atau ILO adalah badan Perserikatan Bangsa-Bangsa (PBB) yang terus berupaya mendorong terciptanya peluang bagi perempuan dan laki-laki untuk memperoleh pekerjaan yang layak dan produktif secara bebas, adil, aman dan bermartabat. Tujuan utama ILO adalah mempromosikan hak-hak di tempat kerja, mendorong terciptanya peluang kerja yang layak,

28Perwita, A.A.B. dan Yanyan Mochamad Yani, Op.Cit. h. 97. 
meningkatkan perlindungan sosial serta memperkuat dialog untuk mengatasi permasalahan-permasalahan yang terkait dengan dunia kerja. ${ }^{29}$

ILO adalah satu-satunya badan "tripartit" PBB yang mengundang perwakilan pemerintah, pengusaha dan pekerja untuk bersama-sama menyusun kebijakankebijakan dan program. ILO adalah badan global yang bertanggungjawab untuk menyusun dan mengawasi standar-standar ketenagakerjaan internasional. Bekerjasama dengan 181 negara anggotanya, ILO berupaya memastikan bahwa standar-standar ketenagakerjaan ini dihormati baik secara prinsip maupun praktiknya. ${ }^{30}$

ILO berusaha mencapai tujuannya melalui, empat kunci sasaran:

1. Mempromosikan dan mewujudkan prinsip-prinsip dan hak-hak dasar di tempat kerja;

2. Menciptakan kesempatan yang lebih besar bagi perempuan dan laki-laki untuk mendapatkan pekerjaan yang layak;

3. Meningkatkan cakupan dan keefektifan perlindungan sosial untuk semua;

4. Memperkuat tripartisme dan dialog sosial. ${ }^{31}$

Terkait dengan dunia kerja khususnya pekerja migran lintas negara, organisasi buruh dunia ILO dibawah naungan PBB sangat konsen untuk melindungi para tenaga kerja buruh migran seperti telah tertera dalam konvensi dengan empat butir diatas. Sehingga setiap negara anggota PBB sebagai negara pihak karena telah meratifikasi adalah wajib bertanggung jawab atas nama seluruh komunitas dunia negara - negara beradab sesuai prinsip-prinsip hukum negara masing-masing disertai dengan mentaati dan menerapkan prinsip universal juga menerapkan yurisdiksi eksrateritorial. ${ }^{32}$

Konvensi ILO merupakan perjanjian-perjanjian internasional, tunduk pada ratifikasi negara-negara anggota. Indonesia merupakan negara pertama di Asia dan kelima di dunia yang telah meratifikasi seluruh Konvensi pokok ILO. Sejak menjadi anggota tahun 1950, Indonesia telah meratifikasi 17 konvensi.

Walaupun negara - negara telah meratifikasi konvesi ILO menyangkut tenaga kerja migran tersebut termasuk Indonesia, namun tetap menganut dan menerapkan prinsip ekstrateritorial non intervensi, yakni melarang negara ikut campur dalam urusan kedaulatan negara lain. Menurut pandangan seorang pakar hukum dari Swiss bernama Emmerich de Vattel menghubungkan prinsip diatas dengan menyatakan bahwa :

"Negara asing tidak memiliki hak untuk ikut campur dalam pemerintahan negara asing. Memerintah diri sendiri sesuai keinginan adalah atribut

\footnotetext{
${ }^{29}$ International Labour Organization, "Sekilas Tentang ILO", URL: http://www. ilo. org/wcmsp5/groups/public/@asia/(a),ro-bangkok/documents/publication/wcmsj)98256.pdf, 2007, diakses pada 26 Mei 2017.

${ }^{30}$ Ibid

${ }^{31}$ International Labour Organization, "Sekilas ILO di Indonesia ", URL: http://www.oit.org/public/indonesia/region/asro/jakarta/download/faktailojkt.pdf, diakses pada 26 Mei2018

32Ireland, D., "Prosecutions of Extraterritorial Criminal Conduct and the Abuse of Rights Doctrine'", Utrecht Law Review Jourmal, , Volume 9, 2013, h. 70
} 
kemandirian. Suatu negara berdaulat tidak boleh diganggu oleh negara lain kecuali jika negara itu telah memberikan hak untuk campur tangan dalam urusan-urusannya". 33

Protokol Penyelundupan Migran ini diadopsi melalui Resolusi PBB A/RES/55/25 tanggal 15 November 2000, dimana sampai dengan juni 2012 tercatat 112 negara penandatangan dan 130 negara peserta. Dalam Preambul Protokol ditegaskan bahwa Negara Peserta (States Parties') menyatakan tindakan efektif (effective action) untuk mencegah dan memerangi penyelundupan migran baik dilakukan melalui darat, laut, maupun udara memerlukan pendekatan internasional komperhensif termasuk kerjasama, pertukaran informasi, dan upaya lain misalnya upaya sosial ekonomi baik pada tingkat nasional, regional dan internasional. ${ }^{34}$

Indonesia telah mengesahkan protokol ini pada tanggal 16 Maret 2009 dengan Undang-Undang Nomor 15 Tahun 2009 (UU1 5/2009) tentang Pengesahan Protocol againts the Smuggling of Migrants By Land, Sea and Air, Supplementing the United Nations Conventions againts Transnational Organized Crime (Protokol Menentang Penyelundupan Migran melalui Darat, Laut, dan Udara, Melengkapi Konvensi Perserikatan BangsaBangsa Menentang Tindak Pidana Transnasional yang Terorganisasi) ${ }^{35}$

Penegakan hukum secara international salah satunya di bidang penyelundupan migran di bidang ketenagakerjaan ada perkembangan baru, Lembaga Peradilan Pidana International (International Criminal Court / ICC) diberikan kewenangan baru oleh PBB melebar untuk menangani kejahatan transnasional bila negara tidak mampu atau tidak mau menanganinya, ICC menuntut serta menghukum pelaku-pelaku kejahatan seperti diatur diluar Pasal 5 dan Pasal 6 seperti kejahatan transnasional penyelundupan migran. ${ }^{36}$

\section{Kesimpulan}

Sebagai kesimpulan dalam penelitian adalah (1) Bahwa pengaturan menurut hukum nasional (Indonesia) bagi tenaga kerja migran lintas negara diatur dalam hukum positif seperti Undang - Undang Keimigrasian, Undang - Undang Ketenagakerjaan, Undang - Undang Penyelundupan dan Pasal - Pasal dalam Kitab Undang - Undang Hukum Pidana, dan pengaturan secara hukum internasional diatur oleh konvensi - konvensi PBB dengan penjabaran melalui konvensi ILO - berupa berbagai aturan multilateral - unilateral - bilateral di bidang perlindungan migran antar negara, lintas negara. (2) Menyangkut perlindungan hukum bagi warganya yang berimigran ke luar negeri / lintas wilayah antar negara bahwa negara asal migran tetap mengembang tanggung jawab perlindungan hukum atas warganya sejauh diperkenankan oleh primat - primat hukum internasional dengan menerapkan prinsip

${ }^{33}$ Gerber, D.J, "Beyond Balancing: International Law Restraints onthe Reach of National Laws", The Yale Journal of International Law Volume 10, 1984, , h h.210

${ }^{34}$ Ibid, h. 164

${ }^{35} \mathrm{Ibid}, \mathrm{h} .165$

${ }^{36}$ Schloenhardt, A. 2005, "Transnational organized crime and the International Criminal Court developments and debates", University of Queensland Law Journal, Volume 24,, URL: http://classic.austlii.edu.au/au/journals/UQLawJl/2005/4.html 
yurisdiksi ekstrateritorial terhadap negara pihak yang kena efek dari adanya pelanggaran yang dilakukan migran negara asal.

\section{Daftar Pustaka}

Buku

Albanese, J.S., Kejahatan Terorganisasi (Organized Crime0 Akar dan Perkembangannya, Edisi Keenam, Prenada Media Group, Jakarta, 2016.

Bayu Perwita, AA dan Yanyan Yani, Pengantar Ilmu Hubungan Internasional, Remaja Rosdakarya, Bandung, 2005

Iman Santoso, Mochamad, Hukum Pidana Internasional, Pustaka Reka Cipta, Bandung, 2013

Nasution, B.J, Metode Penelitian Ilmu Hukum, Penerbit Mandar Maju, Bandung, 2008

Soepomo, I., Hukum Perburuhan, Djambatan, Jakarta, 1987

Starke, J. G., An Introduction To International Law (Pengantar Hukum International), Penyadur : F. Isjwara, Edisi Ke VI, Alumni Bandung, 1972

Teuku, M..R, Hukum Internasional, Refika Aditama, Bandung, 2002

\section{Jurnal}

Boister, Neil. "Transnational criminal law'?." European Journal of International Law 14, no. 5 (2003): 953-976.

Florea, Dumitrița, and Narcisa Galeş. "Sovereign State-The Classic Basic Subject Of Public International Law." The USV Annals of Economics and Public Administration 12, no. 2 (16) (2013): 262-273.

Gerber, David J. "Beyond balancing: International law restraints on the reach of national laws." Yale J. Int'l L. 10 (1984): 185.

Ireland-Piper, Danielle. "Prosecutions of Extraterritorial Criminal Conduct and the Abuse of Rights Doctrine." Utrecht L. Rev. 9 (2013): 68.

Obokata, Tom. "The value of international law in combating transnational organized crime in the Asia-Pacific." Asian Journal of International Law 7, no. 1 (2017): 3960.

Passas, Nikos. "Cross-border crime and the interface between legal and illegal actors." Security Journal 16, no. 1 (2003): 19-37.

De Pue, John. "Fundamental Principles Governing Extraterritorial ProsecutionsJurisdiction and Venue." US Att'ys Bull. 55 (2007): 1.

Orentlicher, Diane. "Whose Justice? Reconciling Universal Jurisdiction with Democratic Principles'(2004)." Georgetown Law Journal 92: 1118-23.

Schloenhardt, Andreas. "Transnational organised crime and the international criminal court developments and debates." U. Queensland LJ 24 (2005): 93.

Sitepu, Aldo Ingo. "Application of Extraterritorial Jurisdiction in European Convention on Human Rights (Case Study: Al-Skeini and Others v. UK)." Indonesian J. Int'l L. 13 (2015): 353.

\section{Website}

International Labour Organization, "Sekilas Tentang ILO", URL:http://www. ilo._org/wcmsp5/groups/public/@asia/(a),robangkok/documents/publication/wcmsj)98256.pdf, 2007, diakses pada 26 Mei 2017. 
International Labour Organization, "Sekilas ILO di Indonesia ", URL: http://www.oit.org/public/indonesia/region/asro/jakarta/download/faktailojkt.pdf, diakses pada 26 Mei 2018

Pusat Kajian FISIP UI, 2014, Persoalan Buruh Migran di Indonesia: IdentifikasiMasalahmasalah Buruh Migran, URL: http://www.puskapol.ui.ac.id/wpcontent/uploads/2014/05 ffact-sheet-2.pdf, diakses pada: 15 Maret 2017

Serena, E., 2014, Konvensi PBB Tahun 1990: Suatu Keniscayaan Dalam Perwujudan Emansipasi 7X7, URL : http://www.kompasiana.com/elsonserenasiagian/konvensipbb-tahun-1990-suatu-keniscayaan-dalam-perwujudan-emansipasitki_54f75b60a3331145398b45dc, diakses pada : 15 Maret 2017

\section{Peraturan Perundang - Undangan}

Undang - Undang RI No. 21 Tahun 2007 Tentang Pemberantasan Tindak Pidana Perdagangan Orang, LN RI Tahun 2007 No. 58, TLN RI No. 4720

Undang - Undang RI No. 6 Tahun 2011 Tentang Keimigrasian, LN RI Tahun 2011 No. 52, TLN RI No. 5216

Undang - Undang RI No. 13 Tahun 2003 Tentang Ketenagakerjaan, LN RI Tahun 2003 No. 39, TLN RI No. 4279

Undang - Undang RI No. 35 Tahun 2014 Tentang Perlindungan Anak, LN RI Tahun 2014 No. 297, TLN RI No. 5606

Undang - Undang RI No. 39 Tahun 1999 Tentang HAM (Hak Asasi Manusia), LN RI Tahun 1999 No. 165, TLN RI No. 3886

Undang - Undang RI No. 6 Tahun 2012 Tentang Pengesahan Konvensi Internasional Mengenai Hak Seluruh Pekerja Migran dan Anggota Keluarganya.

\section{Lainnya}

Annex, I. I. "Protocol to prevent, suppress and punish trafficking in persons, especially women and children, supplementing the United Nations convention against transnational organized crime." In United Nations Office on Drugs and Crime, United Nations Convention against Transnational Organized Crime and the Protocols Thereto. 2000.

Martosoewignjo, S.S, Refleksi HAM di Indonesia, Makalah Penataran Hukum Humaniter dan Hukum HAM. UGM-ICRC. Yogyakarta, 1998,

Santoso, B., 2001, Wawasan HAM dalam Negara Hukum, Makalah Seminar HAM, FHUNS, Surakarta 